\title{
Bean (Phaseolus vulgaris L.) lines: chemical composition and protein digestibility
}

\author{
F.R. Mesquita, M.I.A. Silva and A.D. Corrêa \\ 2005. Universidade Federal de Lavras, Lavras, MG, Brasil \\ Master's thesis. Orienting Prof.: A.D. Corrêa \\ Corresponding author: F.R. Mesquita \\ E-mail: fabriciorivelli@hotmail.com
}

Genet. Mol. Res. 15 (2): gmr.15028587

Received March 1, 2016

Accepted March 1, 2016

Published May 6, 2016

DOI http://dx.doi.org/10.4238/gmr.15028587

The bean represents the main source of proteins for the low income populations, although the digestibility of those proteins is relatively low. Consequently, the programs of plant genetic breeding have been working on the search for new lines with higher protein levels. Thus, with the purpose of supplying information to the researchers, in this study, 21 bean (Phaseolus vulgaris L.) lines were analyzed for the centesimal and mineral composition, protein digestibility, phenolic compounds, and trypsin inhibitor. The entirely randomized experimental design was used with 21 treatments (lines) and three repetitions. All values were within the following ranges: 22.34 to $36.28 \mathrm{~g}$ crude protein/100 g dry matter (DM); 7.56 to $20.91 \mathrm{~g}$ neutral detergent fiber/100 g DM; 0.53 to $2.55 \mathrm{~g}$ fat/100 g DM and 2.97 to $4.87 \mathrm{~g}$ ashes $/ 100 \mathrm{~g}$ DM. The levels of phosphorus, potassium, calcium, magnesium, and sulfur, in $\mathrm{g} / 100 \mathrm{~g} \mathrm{DM}$, varied from 0.45 to $0.72 ; 1.51$ to $2.48 ; 0.03$ to $0.28 ; 0.18$ to 0.34 and 0.28 to 0.45 , respectively. Regarding copper, manganese, zinc and iron, the levels, in $\mathrm{mg} / \mathrm{kg} \mathrm{DM}$, varied from 11.37 to $17.73 ; 14.93$ to $28.90 ; 36.67$ to 69.90 and 71.37 to 126.90 , respectively. The in vitro protein digestibility varied from 18.03 to $48.32 \%$. The levels of phenolic compounds varied from 0.28 to $1.08 \mathrm{mg}$ acid tanic $/ 100 \mathrm{~g}$ DM and the one of trypsin inhibitor from 59.93 to 151.07 trypsin inhibited units/mg DM. Among the lines with higher protein contents, "ESAL 569" (beige with brown stripe) presented the largest protein digestibility and considerable 
levels of minerals. "P-180" (beige with brown stripe) was one of the lines with higher crude protein contents and digestibilities, and also presented high levels for most of the minerals. No relation between protein digestibility and the contents of phenolic compounds or trypsin inhibitor was observed.

Key words: Bean; Phaseolus vulgaris L.; Nutrients; Antinutrients; Protein digestibility 